\title{
CHALLENGES AND OPPORTUNITIES FOR THE EXPANSION OF RENEWABLE ELECTRIFICATION IN KENYA
}

\author{
Mbeo Calvince Ogeya, Philip Osano, Ann Kingiri, \\ and Josephat Mongare Okemwa
}

\begin{abstract}
This chapter investigates the development of renewable grid electricity in Kenya from 1997 to 2019 using four elements of the multi-level perspective framework of socio-technical and economic transition. Opportunities and constraints for the development and growth of the wind and solar electricity subsectors are analysed. The outcome over the 22 -year period has been mixed but remains promising in terms of the potential for increased investments in solar and wind power in rural areas. Five legal statutory and policy milestones facilitated the transformation that was witnessed in the renewable electricity subsector. Notably, the share of non-fossil electricity in the overall mix increased substantially reaching $90 \%$ in 2019, however contribution from wind and solar did not record any remarkable change between 2010 and 2018 - accounting for a high of 3\% share. The coming to grid of the Garissa Solar Plant $(55 \mathrm{MW})$ and the Lake Turkana Wind Power Project $(310 \mathrm{MW})$ in late 2018 pushed the share to a high of $14.6 \%$ in 2020. Even so, factors including power politics, institutional inertia, and societal and cultural constraints have created a lock-in that is likely to limit the full realisation of Kenya's wind and solar energy.
\end{abstract}

\section{Introduction}

Access to modern energy is critical for economic growth, and poverty reduction. Sustainable Development Goal 7 seeks to ensure access to affordable, reliable, sustainable, and modern energy for all by 2030 (United Nations, 2015). Although Africa is endowed with rich energy resources, access to modern energy remains a challenge in the continent whose energy profile is characterised by low production, low consumption, and high dependence on traditional biomass energy. In

DOI: $10.4324 / 9781003054665-3$ 
sub-Saharan Africa, an estimated $83 \%$ of households rely on traditional fuel such as firewood and charcoal for cooking and kerosene lanterns for lighting (Njiru and Letema, 2018). The African Agenda 2063 places a high priority on renewable energy in fostering economic growth and eradication of energy poverty (African Union \& Commission, 2015). Although an estimated 600 million people are without access to electricity in sub-Saharan Africa, there has been marked progress recorded in electricity access. The World Energy Outlook Report for Africa notes that the number of people annually gaining access to electricity doubled from 9 million between 2000 and 2013, to 20 million between 2014 and 2018, with three countries - Kenya, Ethiopia, and Tanzania - accounting for $50 \%$ of those gaining access (IEA, 2019).

Ensuring energy for all is a key priority for African governments, many of which are increasingly investing in clean energy to transition their economies to renewable electricity that is dependent on clean sources such as hydropower, wind, solar, and geothermal. Sustainable transition to renewables is a complex and dynamic process with different policy, economic, social, and technological implications at the local, national, and regional levels.

This chapter presents an analysis of the opportunities and constraints for expansion of renewable electricity in Kenya. Our analysis draws upon the insights from four elements of the multi-level perspective (MLP) framework (Geels, 2011): (i) landscape pressure; (ii) institutional context and legitimisation; (iii) technology, development, and market function; and (iv) agency and power, to provide deeper analysis and evidence focused on the development of solar and wind energy in Kenya.

The chapter is structured as follows: first, the evolution of renewable electrification in Kenya is discussed, providing a context for the chapter through a detailed analysis of how renewable electrification has evolved since 1997 to date. This section exposes the country's energy demand and supply dynamics, and the policies and institutional reforms emanating from and in response to these dynamics. Next, we present the methodology and conceptual framework used. Then the opportunities and constraints for future expansion of the renewable energy sector in Kenya are reviewed using selected elements of the MLP framework followed by a conclusion.

\section{The evolution of renewable electrification in Kenya}

The Kenya Vision 2030, which is the country's development blueprint, aims at transforming the nation into a middle-income country by 2030 and acknowledges energy as one of the infrastructural enablers for this economic growth. As the industrial and manufacturing sectors expand as part of the Vision 2030 implementation, it is expected that energy consumption in these sectors will increase correspondingly, necessitating additional investment and financing to expand electricity to stimulate economic growth in the rural areas (GoK, 2007). The recent technological advancement, donor support, and energy system planning 
witnessed in Kenya have led to the rapid growth of electricity systems and energy access (Byrne et al., 2014). In Kenya, abundant wind, solar, biomass, and geothermal resources have led the government to seek the expansion of renewable energy generation to rural areas (Kiplagat, Wang, and Li, 2011).

\section{Kenya electricity demand and supply (2008-2018)}

The demand for electricity in Kenya has been increasing rapidly due to, among other factors, population growth, economic growth, and increased infrastructure investments in various sectors (Kiprop, Matsui, and Maundu, 2020). A linear steady growth in peak demand has been observed between 2008 to 2018 with an average growth rate of 5.6\% (Kenya Power, 2019). The observed increase in energy demand has also been attributed to the World Bank-financed Last Mile Connectivity Project, and the introduction of the discounted night time electricity tariffs that may have created incentives for manufacturers to upscale the demand for electricity from the grid (Kenya Power, 2018). The Last Mile Connectivity Project has spurred the rapid increase in household connections from about 2.5 million in 2014 to 6.5 million in 2018. Even so, electricity peak demand has continued with a steady growth rate of about $5.6 \%$ annually, and is projected to rise to 4,244 MW in 2030 in the business as usual scenario, assuming historic demand growth trends (Ministry of Energy and Petroleum, 2018; Kenya Power, 2019; KNBS, 2020b). However, in a high growth scenario assuming full implementation of the Kenya Vision 2030 projects, the demand is estimated to reach 5,780 MW in 2030 (Ministry of Energy and Petroleum, 2018).

On the supply side, the effective capacity has increased by about $79 \%$ from $1,267 \mathrm{MW}$ in 2008 to $2,265 \mathrm{MW}$ in 2018 . The trend shows a steady average growth rate of $6.1 \%$ between 2009 and 2014. Two spikes were observed in 2015 and 2019 resulting in higher growth in supply (average 7.5\%) compared to the demand growth rate. These spikes were occasioned by the addition of $280 \mathrm{MW}$ geothermal power in 2015 and 365 MW wind and solar power by 2019. The effective capacity thus increased to 2,631 MW in 2019. Thus, the updated capacity mix as of 2019 was: $745 \mathrm{MW}$ fossil, $786 \mathrm{MW}$ hydro, $649 \mathrm{MW}$ geothermal, 21.5 MW biomass, and 411 MW other renewables - solar and wind accounting for 95\% (Kenya Power, 2019; KNBS, 2020b).

The first on-grid solar photovoltaic (PV) system was realised in 2016 with the commissioning of the $0.25 \mathrm{MW}$ grid-tie solar PV by Strathmore University, followed in 2019 by the 55 MW Garissa solar plant. The first grid-tie wind was realised in early 2000 - a capacity of 0.4 MW piloted in Ngong' Hills Kenya by the Kenya Electricity Generating Company (KenGen). It took about 12 years (to 2011) for KenGen to increase the grid installed capacity of wind power to 5.3 MW and another four years to grow to 25.5 MW in 2015 (Kenya Power, 2004, 2019). Private sector-led Lake Turkana Wind Power (LTWP) dispatched 310 MW wind capacity to grid in 2018, about 13 years after inception of the project in 2005 (Lake Turkana Wind Power Project, 2011). This development explains 


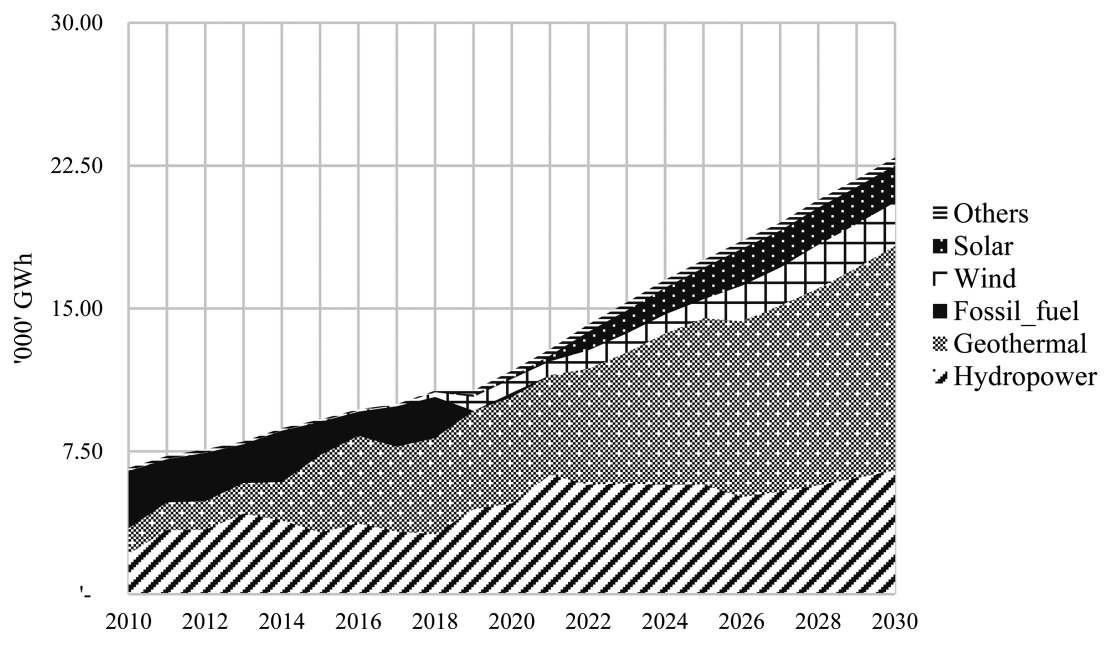

FIGURE 3.1 Projected generation in business as usual scenario. Data Source: authors.

the emergence of solar and wind energy in 2018 as illustrated in Figure 3.1, which presents a forecast of grid electricity supply by different electricity sources until 2030 based on existing and committed generation projects. There is a projected increase in renewables (solar and wind) contribution to about $18.5 \%$ of the total national grid mix by 2030.

Technically, the off-grid solar PV market is highly adopted; however, there is scanty verifiable data sources on the actual installed and effective capacities and proportion of off-grid and grid electricity supply. The national utility offgrid projects were implemented through the Rural Electrification Fund before the establishment of Rural Electrification Authority (REA) in 2006, later converted to Rural Electrification and Renewable Energy Corporation (REREC) in 2019. Until 2011 when 0.6 MW and 0.1 MW solar and wind capacity were installed for institutional electrification mainly in schools, health facilities, and trading centres, there was no data on off-grid solar or wind power generation managed by national utility. In 2018, there was no significant change in the REA off-grid solar and wind accounting for 0.69 MW and 0.55 MW respectively (Kenya Power, 2013, 2018). Other off-grid solutions including solar home systems, micro-solar home system, mini-grids, and solar lanterns have mainly been distributed by the private sector and often are targeted to residential, small, and medium scale businesses. According to the 2019 National Census Report, the share of households with standalone solar PV increased from 140 thousand households to 2.3 million households between 2009 and 2019 (KNBS, 2009, 2019); and another 5.2\% of the total households using rechargeable solar lanterns. Other reports show that about 2.6 million solar PV modules were cumulatively imported into the country by 2017 (RENCON Consulting, 2018). 


\section{Policies and institutional transformations for electrification in Kenya}

Although the history of the electrification process in Kenya dates to the pre- and post-independence period, we take as our reference point the enactment of the Kenya Electric Power Act 1997 to describe the socio-technical transition in the renewable electricity sector in Kenya and end the assessment with the enactment of the Energy Act of 2019 and implementation actions that have since followed the enactment. In the 22-year period from 1997 to 2019, five major milestones were realised in the policy and institutional reforms of electrification in Kenya. These include the Electric Power Act of 1997, the Sessional Paper No. 4 on Energy of 2004, the Energy Act of 2006, the National Energy Policy of 2018, and the Energy Act of 2019. Added to these was the enactment of Constitution of Kenya in 2010 which devolved planning and development of electricity and gas reticulation. The reforms brought about through these successive policies have been directed towards increasing energy demand, electricity access, especially renewable sources in the rural areas, and the expansion of the electricity capacity needed for industrialisation (Abdallah, Bressers, and Clancy, 2015).

The Electric Power Act of 1997 provided for regulation, generation, transmission and distribution, supply, and use of electricity. Amongst other reforms, the Act provided for the licensing and conflict resolution for Independent Power Producers (IPPs). Godinho and Eberhard (2019) note that the structure of Kenya's vibrant energy sector has been transformed by two waves of reforms. The first wave of reform was largely donor driven policy commencing in 1996. As part of this wave, the generation of electricity was separated from distribution and transmission. The second wave of reform commenced in 2002 led by the domestic champions whereby the trust of the first wave continued and independent regulations were strengthened. It included partial privatisation of the generation company, the Kenya Electricity Generating Company (KenGen) Limited (Godinho and Eberhard, 2019).

The Sessional Paper No. 4 on Energy of 2004 laid down the policy framework upon which the quality and affordability of energy services are provided to the domestic sector in the 2004-2023 period. The Sessional Paper also provided a framework for the Energy Act of 2006. The Sessional Paper recognised the challenges in the power sector including weak power transmission and distribution network, high losses, voltage fluctuation and intermittent power outages, high tariffs due to the high costs charged by Independent Power Producers (IPPs), and electricity demand (MoE, 2004). In 2006, the Energy Act 2006 was enacted. It provided for the establishment of the Geothermal Development Company (GDC), Energy Regulatory Commission (ERC), and the Rural Electrification Authority (REA). Moreover, several other new regulations, standards, and procedures were enacted. These included the Grid Code 2008, the Energy (Energy Management) Regulation 2012, Solar PV Regulation 2012, and the Revised Feed in Tariff (FiT) of 2012 (ERC, 2008, 2012; Ministry of Energy, 2012) 
that provided room for increased participation of private actors linked to small renewable energy generation projects.

The 2010 Constitution of Kenya (GoK, 2010) established a devolved system of governance, with energy considered as a component of devolution. The adoption of the new constitution led to the need for a review of energy policy, hence the development of the Energy Policy 2018 (MoE, 2018). The Policy, as well as the Energy Act 2019, stipulates the functions and roles of the ministries responsible for energy at the national and county levels. The national government provides overall guidance on policy, planning, and public investment. The county is responsible for amongst other things county planning, development including electricity and gas reticulation, implementation of county electrification programmes, and establishment of energy centres for promotion of renewable energy technologies, energy efficiency, and conservation. A number of policies, including the Energy Act of 2019, thus provide for a more consumer-oriented approach to energy generation and supply (GoK, 2010, 2011; The Energy Act, 2019, 2019).

The structural changes brought about by the Energy Act 2019 include the establishment of the Energy and Petroleum Regulatory Authority (EPRA), previously referred to as the Energy Regulatory Commission (ERC). The authority takes up all responsibility of the commission including enforcing local content requirements and regulation, issuing licences, setting tariffs, and approving power purchases and network contracts. It is also mandated to negotiate the power purchase agreements between the Kenya Power and Independent Power Producers. The Energy and Petroleum Tribunal was created to take over the functions of the Energy Tribunal. It is mandated to hear and determine energy and petroleum related disputes and appeals. The establishment of the Rural Electrification and Renewable Energy Corporation (REREC) took over the functions of the Rural Electrification Authority (REA). The Corporation is mandated to inter alia source additional funds for renewable energy; develop renewable energy master plans; and develop, promote, and collaborate with other agencies in the use of renewable energy technologies. Figure 3.2 shows a visualised summary of the transformation in the electricity sector policy.

\section{Drivers of policy change and conditions for transformation}

Energy has been identified as a strong pillar in Kenya's national development. It is critical in supporting Kenya's Vision 2030 in the area of manufacturing, agriculture, and commercial sectors (economic pillars) and education, health, gender equity, and environment (social pillar) (GoK, 2007). In addition, the focus of the Vision 2030 Medium Term Plan for the 2018-2022 period is on the Big 4 Agenda of Manufacturing, Improved Health, Affordable Housing, and Food Security.

Informed by the national policy agenda outlined above, we argue that the drivers of policy changes at the macro level are primarily economic growth, 


\section{Transformation in the electricity sector 2000-2020}

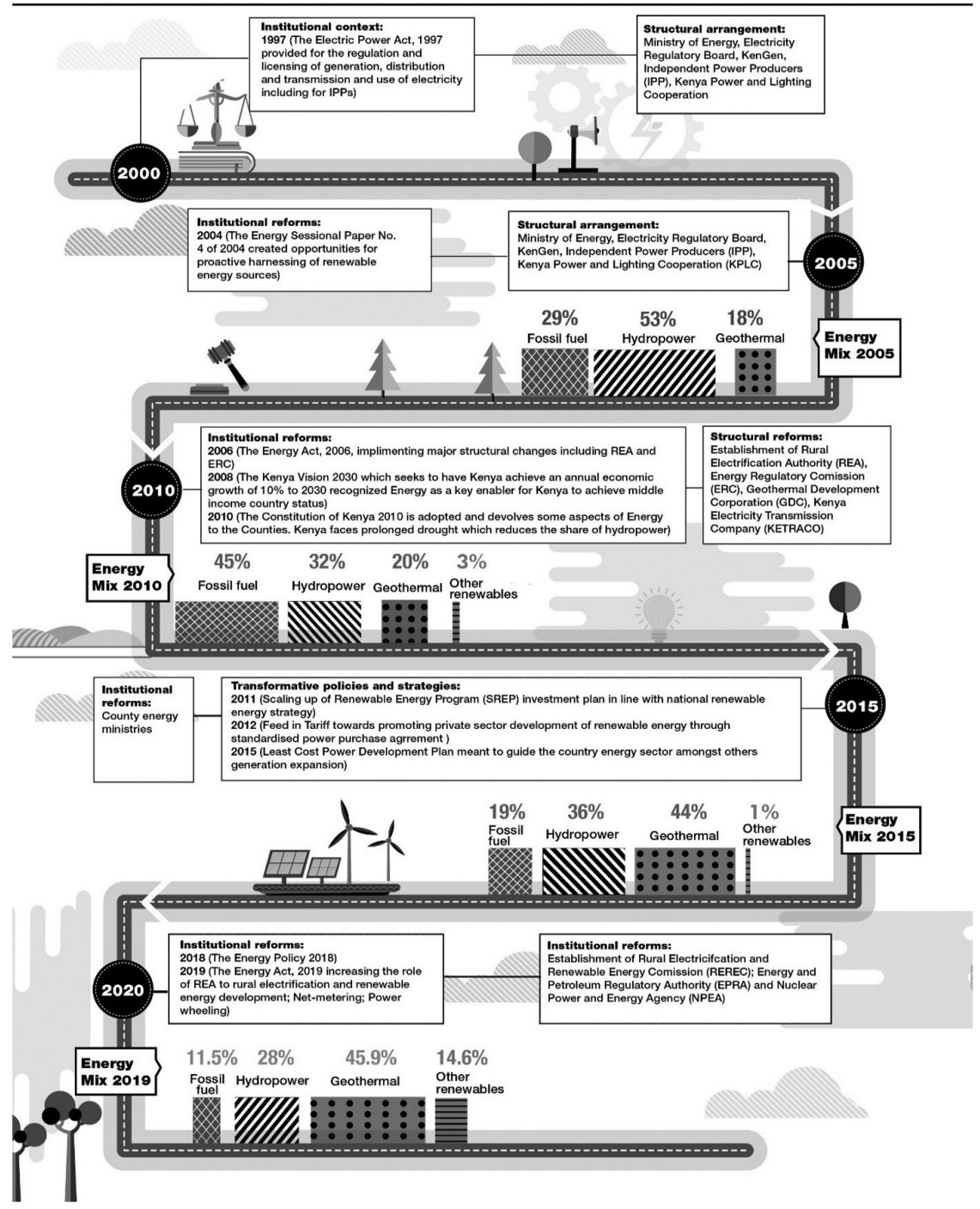

FIGURE 3.2 Policy transformation in the electricity sector. Acronyms: REA = Rural Electrification Authority; REREC = Rural Electrification and Renewable Energy Corporation; EPRA = Energy and Petroleum Regulatory Authority; LCPDP = Least Cost Power Development Plan. Source: authors. 
industrial development, demographic change, and climate change. This comes with the need for promotion of energy efficiency, fostering international cooperation, capacity building in the energy sector, diversification of energy supply sources in ensuring security of supply, protection of investors, and promotion of cost effective and equitable pricing of energy products. Kenya has committed to the Sustainable Development Goal and put in place measures aimed at achieving Goal 7. Currently an estimated 11 million people do not have access to electricity (IEA, 2019; Kenya Power, 2018). Arguably, electricity access is attributed to increased economic growth, better provision of public service, and quality of life, as well as technological advancement in education, health, and agriculture (Blimpo and Malcolm, 2019).

Efforts towards economic growth and industrial development in the renewable energy sector have been perpetuated through international technology transfer and deployment. Ockwell et al. (2009) observe that proactive technology transfer can be equated to underpinned long term low carbon transfer which requires development of innovative capabilities, especially in developing countries. More important for the energy sector - which is our motivation for this chapter - is the policy change at the micro level that relates to building requisite local capabilities to enhance indigenous or local technological solutions. Kenya's universal access to electricity can only be achieved based on, in part, concerted efforts to enhance local capabilities that would promote both grid and off-grid technological solutions. Several publications expound on the nature of capabilities that are needed in this regard. These include organisational capabilities synonymous with 'innovation management', human capabilities, technological capacity, and policies (Lawson and Samson, 2001; Nussbaum, 2001; Ockwell et al., 2009). In acquiring innovation capabilities, developing countries governments, firms, and organisations learn through the process of technology transfer and deployment. This learning process is an accumulation of relevant capabilities whereby an integrated approach in technology transfer and local innovation in renewable electrification are complementary (Lema et al., 2018).

\section{Methodology and conceptual framework}

\section{Data collection and analysis}

The information and data used for this chapter were collected using several methods. We used secondary data on electricity demand and supply which was collated from institutional databases and reports. We carried out desk review of peer reviewed and grey literature looking at solar and wind subsectors and the entire renewable sector in Kenya. We also conducted document analysis of the policies that we reviewed. The systemic analysis of policy documents served to generate empirical data that informed an in-depth interrogation of the dynamics that constrain or support the sector's growth. The authors also participated in several policy processes and workshops, which allowed us to access useful materials such 
as presentations. Useful information was also obtained through both structured and unstructured interviews and informal conversations with key informants in the energy sector. The use of different sources enabled us to triangulate the data, thereby ensuring greater reliability and validity of the information and data that we used in our analysis.

The overall analysis was conducted using qualitative and quantitative methods. The qualitative information and data were first documented, and themes categorised according to the challenges and opportunities in the renewable energy sectors for both solar and wind. The recurring themes were highlighted and interpreted as critical observations by the authors. The quantitative data on the demand and supply was analysed using excel spreadsheet and the LEAP (Long Range Energy Alternative Planning) tool to obtain the energy demand projections for 2030 .

\section{Analytical framework: the multi-level perspective (MLP) in articulating challenges and opportunities for renewable electricity}

Sustainable transition is viewed as multi-dimensional in nature because it involves a broad range of interacting actors and processes, including technologies, policy or power politics, economics or market space, and cultural expositions and the dynamics of structural changes (Geels, 2011; Smith et al., 2010). It is noted that the transition dynamics include mass (objects, actors, and infrastructure involved), speed (the pace at which socio-technical and their alignment develops), and direction (overall performance of system changes as a result of innovation), and in the process new products, services, business models, and organisations emerge, partly complementing and partly substituting existing regime (Farla et al., 2012; Smith et al., 2010).

Although the environmental push has significant influence on the sociotechnical transitions, there are inherent systemic factors that seek to ensure that the norm continues (Geels, 2011). Many of such existing structural systems are stabilised through various lock-in mechanisms, for example economy of scale, sunk capital investment, infrastructure, and competencies (Geels, 2011). These lock-in systems make it difficult to extricate existing systems (also known as regime) or create tension. The multi-level perspective therefore conceptualises overall dynamics of patterns in socio-technical transitions. It views transition as a non-linear process that results from the interplay of development at three analytical levels: (1) niches (entrepreneurs, spinoffs, and start-ups innovating against regime); (2) socio-technical regimes (structures accounting for stability in a system); and (3) exogenous social-technical landscape (wider context which influence niche and regime) (Geels, 2011; Smith, Voß, and Grin, 2010).

The socio-technical regime is the structure that accounts for the stability of the existing socio-technical system. It is the set of rules that orient and coordinate the activities of social groups that reproduce the various elements of 
socio-technical system (Geels, 2014). Such rules include institutional arrangements, national policies and regulations, binding contracts, as well as social economic aspects of routines and shared believes, capabilities and competencies, lifestyle, and practices. Niche is described as a protected space, demonstrator projects or small market niches of special interest to demand actors who are willing to support the innovation (Geels, 2011). Niches have potential to disrupt regimes. Landscape is the wider context which influences niche and regime dynamics. This would include demographic trends, political ideologies, societal values, and micro-economic drivers such as the household income base. These are exogenous factors that niche and regime cannot influence in short term and they take a long time to make significant change.

This paper draws on four elements of the MLP as an analytical framework in building the discourse of energy transition in Kenya with a focus on wind and solar. These are: (1) the landscape pressure, referring to the demographic trends, macro-economic patterns, and societal values that influence regime and niche; (2) institutional context and legitimisation, referring to the legal frameworks within which a socio-technical transition occurs; (3) technology, development, and market function, as a sub-regime where innovations are tested and developed incrementally that could accumulate to stable trajectory; and (4) agency and power, which refer to the governance and the role of power politics in social-technical transition (Geels, 2014). We apply these elements in the analysis of both the opportunities and constraints.

\section{Opportunities for future expansion of renewable electricity in Kenya}

This section attempts to unearth the underlying opportunities for future grid expansion and the implications for renewables, particularly solar and wind.

\section{The landscape pressure}

The landscape pressure issue is mainly linked to economic, demographic, and environmental trends in Kenya. A stable intercensal population growth rate of 3.4\% was observed between the 1962-1969 period and the 1979-1989 period, which then dropped to $2.9 \%$ for the following two decadal periods between 1989 and 2009. A further drop to 2.2\% was marked in the 2009-2019 period (KNBS, 2020a). The country registered an increased economic growth rate from $1.8 \%$ in 2008 to a peak of $8.4 \%$ in 2010 , followed by a decline to $4.6 \%$ in 2012 . This was followed by a generally stable growth rate between 2012 (5.7\%) and 2018 (6.3\%) (KNBS, 2019).

The high growth trajectories and demographic trends have compelled the government to take different approaches in energy growth focusing on least cost power development plans (Ministry of Energy, 2011; Ministry of Energy and Petroleum, 2018). This planning process has also been influenced by the 
impacts of climate change and international obligations. As a signatory to the United Nations Framework Convention on Climate Change (UNFCCC) and having submitted the Nationally Determined Contribution (NDC) to the UNFCCC, Kenya is obligated to reduce emissions of greenhouse gases, including investing in clean and renewable energy with the consequent impact of the grid energy mix.

\section{Institutional context and legitimisation}

The energy reforms in Kenya were re-ignited in 2004 upon the enactment of the Sessional Paper No. 4 on Energy, which created multiple opportunities within renewable energy and rural electrification. It laid a policy framework upon which cost effective, affordable, and adequate quality energy services are to be made accessible to the national economy over the period between 2004-2023 through policy and structural transformation (MoE, 2004). Since then, several policies and regulations have enabled changes within the energy sector resulting in the deployment of renewable energy technologies, learning, and local capacity improvements for rural development.

A more detailed analysis of the transition of energy policies and regulation in Kenya and how this relates to opportunities to build requisite capabilities for renewable technologies diffusion is presented in Kingiri and Okemwa (this volume). The five legal and policy instruments that have been implemented to facilitate the transition to a more sustainable energy generation, transmission, and consumption ensuring reliability, price competitiveness for universal electrification, and economic growth, are highlighted below.

\section{The Energy Act 2006 and Energy Act 2019}

The Act provided for the creation of the Rural Electrification Authority with the mandate to plan and implement electrification programmes in rural areas. This highlights the importance of rural electrification at the time of developing the Act, hence the need for a dedicated agency. The Act liberalised electricity generation - especially the micro and mini power plants below one megawatt - a provision that has been maintained in the Energy Act 2019 under Section 117 (The Energy Act, 2019). As per the Act, there is no statutory obligation for own generation and use of electricity below $1 \mathrm{MW}$. Several private companies have invested in their own renewable electricity generation and community power plants, especially from small and micro-hydropower. Examples of such power plants include Brooke Bond, Tenwek Hospital, James Finley Tea Factory, Thima, Tungu Kabiru, Kathamba, Imenti, Diguna, and Munjwa (Mbaka and Mwaniki, 2016). This is a great opportunity for small scale producers and processors, especially in the rural areas whose electricity demand is below $1 \mathrm{MW}$. 


\section{Feed in Tariff}

The Feed in Tariff (FiT) first issue was released in 2008. This was followed by two more revisions to the latest revised FiT policy of 2012. It stems from the Sessional Paper No. 4 on Energy 2004 and Section 103 of the Energy Act of 2006 , both seeking to promote renewable energy generation. It presents a standardised power purchase policy for small scale renewable energy generation less than $10 \mathrm{MW}$ and provides for review every three years. The standardised Power Purchase Agreement (PPA) features included sales at distributor level, first come first serve basis, and PPA offered to projects that demonstrated technical and economic viability and met all technical requirements for grid connection. This policy presented an opportunity for private sector development of renewable electricity to grid, especially solar and wind.

Experts in the sector observe that the potential of the FiT has not been realised, especially for solar and wind technologies. This is in part due to many non-committal applicants whose expression of interest totalled to over 3,418 MW (wind and solar) by the end of 2018 (MoE, 2018), but only about $11 \%$ had been realised by 2020. Since the establishment of the FiT policy in 2008, the first grid-tie solar within FiT framework (0.25 MW capacity) was reported a decade later in 2018 (Kenya Power, 2019). Some experts in the Ministry of Energy (MoE) attributed this delay to slow demand, utility unpreparedness, and lack of grid stability. The FiT policy has been upheld in the Energy Act of 2019 for the special purposes of catalysing renewable energy uptake, building local networks, stimulating innovation, and reducing GHG emissions. There are, however, ongoing debates for an auction system for variable renewable electricity generation for grid to be based on cost competitiveness. A similar programme - the South Africa Renewable Energy Procurement Program - provides a model for a successful power auctioning. In the past four competitive tendering processes, a total investment of USD 19 billion has been made, and the price of wind and solar fell by 46\% and 71\% in nominal terms between 2011 and 2016 (Eberhard and Kåberger, 2016).

\section{Renewable energy regulations}

There are five existing regulations and two proposed in the renewable energy sector. Table 3.1 lists these regulations with a description of their provisions. These regulations seek to ensure conformance to standards and codes of practice and have promoted formal capacity building, especially in the energy efficiency and photovoltaic (PV) sector.

A requisite certification to engage in the solar PV business and installation and as a certified energy manager requires tailored training. Both formal and professional associations have participated in this certification process and are conducting regular trainings. Before 2012, there were no certified solar PV technicians and energy managers in Kenya. At the time of writing this chapter, there 
TABLE 3.1 Summary description of existing and proposed Renewable Energy Regulations

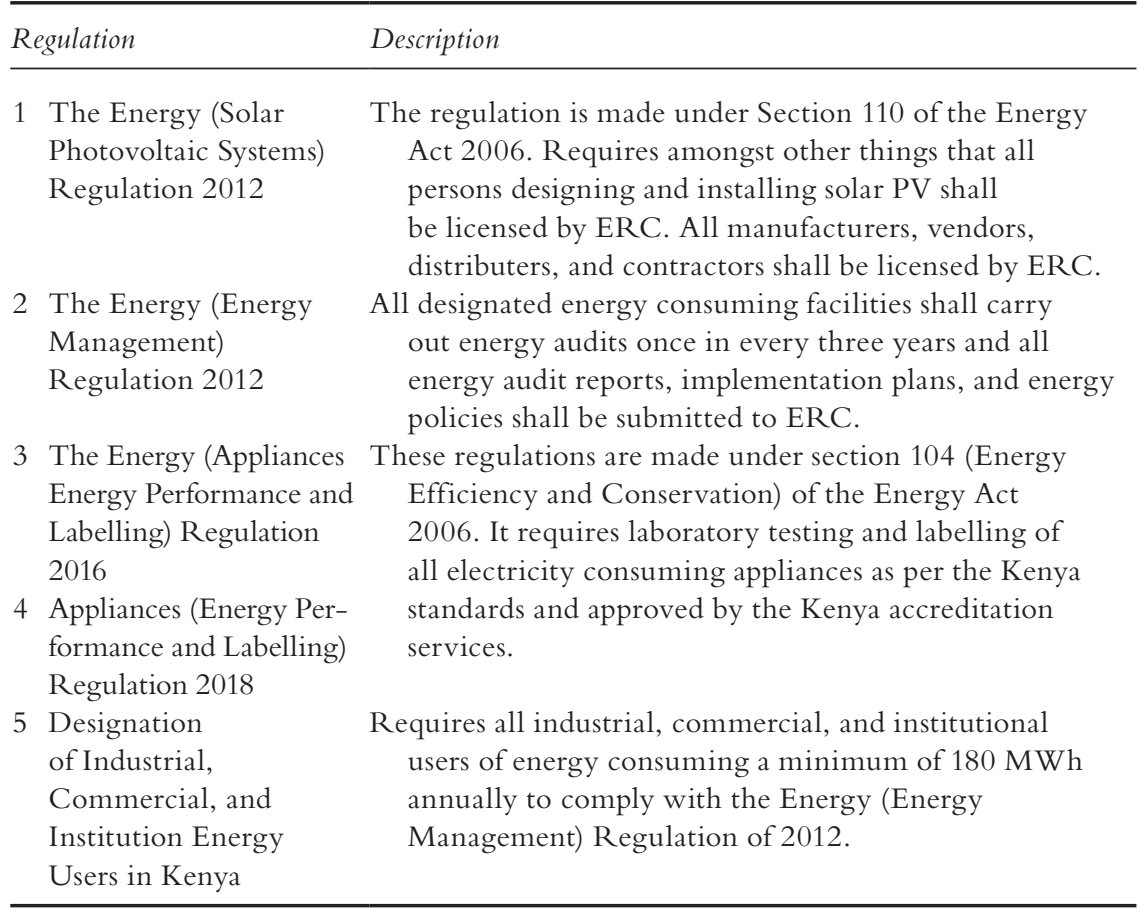

Source: authors.

were about 485 registered certified solar photovoltaic contractors in classes of design and installation (class C1), design, installation and sales (class V1), and manufacture and/or importation of solar PV (class V2), and 376 registered technicians (EPRA, 2020). This capability has an opportunity for quality design and installation works, thereby enhancing rural electrification (EPRA, 2020). Fundamental questions raised during the discussion with stakeholders in the sector relate to effectiveness and implementation of the regulations. Stakeholders cited the lack of personnel capacity that has undermined the implementation of these regulations. The issues of capabilities have been cited as very instrumental in the sustainable industrialisation of the renewable energy sector in Kenya (see Kingiri and Okemwa, 2022; this volume).

\section{Net metering}

Net metering is a new provision under the Energy Act of 2019 and provides for any generator to supply the distributor through the net metering system. Section 162 of the Energy Act 2019 provides for consumers with electricity generators not exceeding $1 \mathrm{MW}$ to enter into net metering agreement with electricity distributors or retailers. However, the implementation framework has not been 
developed for the same. Roux and Shanker (2018) make a comparative study on net metering policies in emerging and developing countries (two in Asia and six in Africa including Kenya). The comparative study elaborates key insights to effectively implementing net metering policies in emerging and developing economies. Such include compensation analysis that comes with net metering, political will, and implementation phases, e.g., commercial users first, then both residential and commercial users (Roux and Shanker, 2018). Even so, this is an opportunity for support of industrial production of solar PV to support adoption.

\section{Power wheeling}

'Power wheeling' is a term often used to describe a consumer transport of electricity from a generation source to a user point, paying service charges to transmission and distribution companies. It is also a new provision under the Energy Act 2019 to enhance power transmission between generator and user through paying service charges. This is a way to enhance private sector engagement in competitive tariffing through own power generation and use.

\section{Technology, development, and market function}

There are numerous niches at different levels within the energy system. The Kenyan renewables market has attracted numerous innovations in technology, business models, and supply chain, particularly in off-grid systems (Basu and Marett, 2016). These innovations have contributed greatly to electricity access. They are supported by the transformation in the policy regime and are gaining traction rapidly with evident disruption in the policy regime. Whereas the gridtie solar PV is yet to develop and attract broader attention apart from e.g., the Garissa solar system in Kenya (see Hanlin and Okemwa, 2022; this volume), the off-grid systems have particularly matured in East Africa with remarkable innovative approaches (see Karjalainen and Byrne, this volume).

M-kopa is one such niche innovation, which was reported to be ranked amongst the world's top ten most innovative companies by Fast Company News (Fast Company, 2020). M-kopa implements a pay-as-you-go business model supported by mobile money transfer. In 2018, about $40 \%$ of Kenya's population had access to a mobile phone and were registered to enable them to do mobile money transfers (M-Pesa) (M-Kopa Solar, 2015). This provided an opportunity for a wider market reach and establishment of the innovative business models. The company's support is based on consumer asset financing through flexible credit facility. Its technology platform combines embedded global systems for mobile communication (GSM) and mobile payments. In only eight years of establishment between 2012 and 2020, about 750,000 homes were connected to M-Kopa-based micro-solar home systems with an average of 500 new connections made daily (M-Kopa Solar, 2020). BBOXX limited solar home system is another example of innovation within the off-grid solar home systems. 
The remotely managed system has a flexible three-year payment plan increasing its reach in the market. These innovative approaches present opportunity for increased demand in off-grid solar, creating opportunities for local capacity development and expansion of solar and wind energy.

\section{Agency and power}

Urban and rural electrification advancement has been made possible as a result of the structural changes undertaken in the power sector. Rural electrification increased from 4\% in 2004 to 23\% in 2018 (Kenya Power, 2019; MoE, 2004). Figure 3.3 provides an illustration of the structural transformations that took place from 1997 to 2019. These were made possible because of the implementation of the Electric Power Act (1997), the Energy Act (2006), and the Energy Act (2019), named as first, second, and third waves of restructuring, respectively. It also includes information on how these three waves of restructuring presented opportunities for expansion of renewable energy in Kenya.

In the first wave of restructuring occasioned by the Electric Power Act 1997, the management of Kenya Power Company (KPC) - the electricity-generating arm of Kenya Power and Lighting Company (KPLC) - was separated and renamed KenGen in 1998. Kenya Power and Lighting Company (KPLC) remained with a dedicated mandate for electricity transmission and distribution, and KenGen as the State Corporation, remained with the mandate for electricity generation (KenGen, 2020). Under the Electric Power Act 1997, the power sector had three main actors; the Ministry of Energy, Kenya Power and Lighting Company, and KenGen (The Electric Power Act, 1997).

The second wave sought to perpetuate privatisation of electricity generation and distribution to enhance opportunity for private sector involvement in
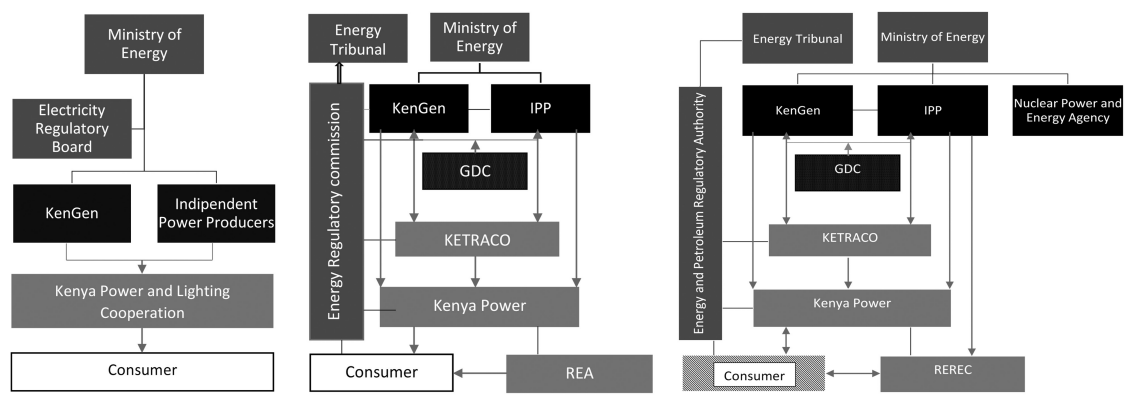

FIGURE 3.3 An illustration of the structural changes in electrification (1997-2019). Source: authors; based on the Electric Power Act 1997; Energy Act 2006; and Energy Act 2019. 
renewable electricity generation and distribution as was recommended in the Sessional Paper No. 4 on Energy of 2004 (MoE, 2004). The privatisation started with KenGen selling 30\% of its shares through public offers and the unbundling of Kenya Power and Lighting Corporation into three entities; Kenya Power (49.9\% privately owned), Kenya Electricity Transmission Company (KETRACO) (100\% government owned), and the Rural Electrification Authority (REA) (also 100\% government owned). This thus called for an independent regulatory authority and a tribunal as confirmed in the Energy Act of 2006 (The Energy Act 2006, 2006). Kenya Power Company received the mandate to continue with distribution and management of old transmission lines and KETRACO was mandated to build new high voltage transmission lines. The common transmission infrastructure could support private sector investment and promote private distributors to enhance efficiency. The Rural Electrification Authority (REA) would venture an aggressive rural electrification programme with a target of reaching 40\% rural electrification by 2020 (MoE, 2004).

The third wave creates opportunity for consumers to enhance adoption of rooftop solar under net metering and strengthen REA by transforming it into a state corporation, increasing its ability to promote renewable electricity in rural areas. The corporation adopts all functions of REA and much more, including sourcing additional funds for renewable electrification and developing and updating the Renewable Energy and Rural Electrification Master Plan in consultation with the county governments (The Electric Power Act, 1997; The Energy Act 2006, 2006; The Energy Act, 2019, 2019).

\section{Constraints to future expansion of renewable electricity in Kenya}

This section presents various constraints that would affect further expansion of renewable electricity in Kenya. Applying the MLP framework, we look at the constraints based on four elements; landscape, institutional context and legitimisation, technology development, and agencies and power.

\section{The landscape pressure}

In a rapid industrialisation landscape, a stable generator such as hydropower and other fossil-based sources would be preferred. According to the Kenya Vision 2030 , economic growth outlook is projected at an annual growth rate of $10 \%$ higher than the current average of $5.7 \%$. Upon implementation of the flagship projects, the national electricity demand pressure would exceed the rate of progression of renewable electricity (GoK, 2007; Ministry of Energy and Petroleum, 2018; KNBS, 2019). For instance, the development of Lamu Coal Power Plant is based on the projected expansion of infrastructure in the northern transport corridor, including the Lamu Port, South Sudan, Ethiopia Transport Corridor (LAPSSET) infrastructure. However, there is uncertainty around the 
government commitment to replace completely fossil-based energies. Arguably, the political economy of the energy sector would have a large influence on the choices and decisions to invest in renewables, including wind and solar.

\section{Institutional context and legitimisation}

In 2020 there were no known regulations enforcing power purchase agreement, yet it is a major determinant to electricity pricing and development of renewable energy. In an open market, the agreement lies between the buyer and the seller. Often, the contracts are defined with a take or pay system rather than energy delivered. As such, even with the rapid decline in fossil fuel-based generation, electricity tariffs remain high resulting in cost related bottlenecks to new customers and electricity consumption, and consequently constrained demand and reduced requirements for new generation. Moreover, the persistent high electricity prices can potentially be a factor contributing to unintended consequences of other policies. For instance, the high prices of electricity from the grid in combination with the net metering policy is likely to catalyse high levels of own generation, especially from solar PV, depriving Kenya Power of revenue.

Stakeholders consulted for this study emphasised that contractual obligations of the utility with power vendors have affected electricity tariffing. Future demand and supply forecast demonstrate a possibility of a grid free from fossil fuels except for grid stabilisation, yet the average cost of fuel charge is USD 4.5 cents/kWh which is about $20 \%$ and $30 \%$ overall electricity cost per kilowatt for domestic tariff one and domestic tariff two respectively (Regulus Limited, 2020). The statutory levies and charges account for about $44 \%$ of the total electricity bill. Institution-based levies include Energy and Petroleum Regulatory Authority levy, Water Resources Management Authority Level and Rural Electrification Program levy and other operational related levies and taxes include Value Added Tax, Fuel Cost Adjustment and Foreign Exchange. The variable charges are dependent on mainly global economic factors such as fossil fuel levy, inflation adjustment, and foreign exchange rate fluctuation adjustment related to fluctuation of hard currency against the Kenya shilling. Water resources levy is charged per $\mathrm{kWh}$ generated from hydro sources above $1 \mathrm{MW}$ and charged at five cents per kilowatt hour. The four-variable electricity costs, including inflation adjustment, fuel costs, water resource management authority fees, and foreign exchange rate fluctuations, are published in the Kenya gazette on a monthly basis along with the trends in the past ten years (ERC, 2018). These and other charges have constantly maintained high tariffs with barely observed reductions irrespective of changes in the sector.

\section{Technology, development, and market function}

Most of the renewable energy technologies used locally are either sourced or imported from abroad. This presents several challenges including potential loss 
of foreign exchange and operations. This presents a bigger challenge related to technology transfer and adoption, and the extent to which this enhances local capabilities. We find this critical because the Energy Act 2019 to some extent provides for local content requirement which is intended to support the growth of local manufacturing.

This study shows that both wind and solar technologies are externally sourced, which has implications for technology development and deployment. Kenya over-relies on external support in four critical elements in technology development and transfer, namely equipment manufacturing, project development, construction and installation, and operations and maintenance (see Hanlin and Okemwa, this volume). Overall, Kenya imports almost all its equipment/ technologies including solar and wind accessories. Most grid-tie project developments have been led by external consultants, and construction and installation is often sub-contracted to equipment suppliers. For instance, Vestas Limited was tendered to supply and install wind turbines in the LTWP project. Mostly local engineers are trained to operate the plant, but there are still high levels of dependency on external capacity for maintenance.

From a collaboration perspective, this highlights potential for foreign firms to contribute to local capabilities, but currently the policies are not clear on how the local content requirements should be implemented to ensure support for local manufacturing and industrialisation more generally.

\section{Agency and power}

\section{Institutional monopoly and lack of capacity}

Kenya Power and KenGen are the dominant agencies in the power sector based on the market shares they hold. Kenya Power is currently a monopoly, being the only legally recognised distributor of grid electricity in Kenya. KenGen is also a dominant producer because it currently controls a $75 \%$ share of the total electricity generation portfolio. This is despite the fact that both the generation and distribution of energy has been liberalised through the Energy Act $(2006,2019)$. However, the levels of control of the market by these two state agencies have created an artificial monopoly that is entrenching a system lock-in. The newly created agencies largely rely on Kenya Power's existing infrastructure, such as networks, transmission, and distribution lines, and financial collection systems, and KenGen's technical artefacts, such as exploration tools, data collection equipment, and historic surveys. Both REREC and KETRACO depend heavily on this established system and this dependence can create serious obstacles to innovation. The dominance by Kenya Power in the distribution sector creates a strong resistance to change and limits the potential emergence of new distribution companies and/or distribution models. The Energy Act 2019 provides for electricity retail through existing distribution lines at a cost determined by the licensee of the distribution line. Hence, whereas the institutional adjustments 
intended to be transformative, the knowledge, technology, and governance base is likely to remain unchanged for the near future.

\section{Societal and cultural constraint}

Key constraints for investments in solar and wind in Kenya are land policies and poorly developed land markets. The land tenure system in Kenya classifies land into four categories: public land, private land, community land, and forest land. While state corporations and agencies can compulsorily acquire land for infrastructure development, the high cost of land is sometimes very prohibitive. The challenge is more acute for private sector developers who have to negotiate directly with landowners for investments that target private and community land. As an example, the development of an evacuation high voltage line from Lake Turkana Wind Power was delayed by more than a year occasioned by challenges in obtaining wayleave access. Other renewable energy projects have struggled to get financial approval due to lack of necessary land rights documents. In other cases, rent-seeking behaviour, which has led to inflation of land purchase and lease prices, is becoming a major hindrance to investments in wind and solar plants. The environmental safeguards, such as environmental and social impact assessments, have in some cases also been faulted.

\section{Resistant to change}

It was noted during the stakeholder's engagement and mapping that some actors can be very influential in the value chain, even though they actually may be less influential in the contribution to systemic changes in policy processes. For instance, even though community members are mainly consulted during the environmental and social impact assessments, in which case they can provide information on their perceived positive or negative impact of the project to the community, they remain critical actors because they own the land on which the renewable electricity projects are developed. Virtually all renewable energy resources that are not on public land are located on land that is owned by a community or private entity. Land in Kenya has strong socioeconomic ties and is considered important as a source and means of wealth, and for agriculture, especially by the rural poor who form the majority of the population (Holde, Otsuka, and Place, 2010). Already, this valuable resource is shrinking with the swelling population, climate change impact, and migration. In some cases, it contributes to one's social status in a society, and in other cases it is important for cultural practices such as shrines. Any policy touching on land is in itself very sensitive. It has remained status quo, and the responsibility of investors to negotiate their way with the communities, including seeking wayleaves, makes it very difficult for investment. Kenya Power (2019) reports that land tenure has become one of the major bottlenecks in extending electricity in rural areas. Aggravating the land-based challenges is tied to the political angle of land ownership. Boone 
reiterates that land politics is a redistributive game that creates winners and losers (Boone, 2012).

\section{Political will}

Politics and power struggle have affected the investment (public and private) in the renewable energy sector, especially grid-tied investments. The nature of the sector as a business opportunity and power influence has made it critically political. In a focus group discussion, it was observed that the business angle has often blurred decision making, often resulting in partisan interests superseding objective analysis and decisions based on evidence. With the exploration and extraction of oil in Turkana and coal in Kitui, the country is at a crossroads of defining its energy future. A just transition to a low carbon economy that delivers poverty reduction and resilience and a more development-oriented growth presents a political decision dilemma. Who sets the terms of transitions and for whom? This raises political questions about the role of actors and whose interest takes preference (Newell et al., 2014). Political economy will therefore continue to play a key role in defining technological and social outcomes.

\section{Conclusion}

The renewable electricity subsector in Kenya has indeed changed from 1997 to 2019. Based on four elements of the multi-level perspective framework of socio-technical and economic transition, in this chapter we have analysed and discussed the opportunities and constraints for the development and growth of the wind and solar energy subsectors. The analysis showed a mix of opportunities and constraints but largely remains positive towards increased investment in renewable electricity (solar and wind) for rural electrification. During the period of the analysis, five major statutory and policy milestones facilitating the transformation in the energy sector were realised. Besides the Constitution of Kenya (2010), which devolved planning and development of electricity and gas reticulation, and energy regulation, the Electric Power Act (1997), the Sessional Paper No. 4 on Energy (2004), the Energy Act (2006), the Energy Policy (2018), and the Energy Act (2019) all presented different provisions for the creation of institutions and processes that promote investment in rural electrification and renewable energy, including solar and wind. These policy and structural changes in the electricity sector present opportunities and constraints in future renewable electricity development in Kenya as summarised below.

The opportunities in future deployment of renewable electricity include, inter alia, the high economic growth rate (an average of 5.6\% annually) and a steady demographic growth (2.2\% annually), significantly increasing energy demand. Renewable electricity is perceived to enhance job creation and employment, deriving more stakeholders' interest and private sector investment. The various legislation and policies, including the Feed in Tariff (FiT), net metering, 
and power wheeling, enhance increased harnessing of renewable electricity, especially by facilitating increased investments by the private sector. They also enhance flexibility of own generation and use of electricity. Finally, the unbundling and privatisation in the energy sector has broken institutional monopolies and could potentially increase private sector investment in renewable electricity generation.

Some of the glaring constraints in expansion of renewable electricity in Kenya could also be associated with high demand. A high double digit annual economic growth rate of $10 \%$, as envisaged in the Kenya Vision 2030, could create more pressure on existing supply which may necessitate immediate investments in new power plants. Moreover, high dependency on foreign support in development of these renewable energy technologies limits the opportunity to develop and promote home-grown technologies in future renewable energy development. As reported in other chapters (see for instance Hanlin and Okemwa, 2022; this volume), besides manufacturing, Kenya relies heavily on foreign support in project development, construction and installation, and operation and maintenance.

The energy sector like other sectors also suffers political economy issues and this influences how things unfold, especially in the grid electricity subsector. Lastly, difficulties in negotiating purchase and leasing agreements on private and community land due to the sensitivity of land issues further limit investments in wind and solar PV projects.

\section{Acknowledgements}

Support for research on which this chapter is based from the Danish Ministry of Foreign Affairs, Grant: DFC 14-09AAU is gratefully acknowledged. We also acknowledge the IREK team especially the editors for insights, information, and valued critique.

\section{References}

Abdallah, S.M., Bressers, H. and Clancy, J.S. (2015) 'Energy reforms in the developing world: Sustainable development compromised?', International Journal of Sustainable Energy Planning and Management, 5, pp. 41-56. https://doi.org/10.5278/ijsepm.2015 .5 .5

African Union \& Commission (2015) Agenda 2063: The Africa We Want. https://www .un.org/en/africa/osaa/pdf/au/agenda2063.pdf

Basu, A. and Marett, D.J. (2016) Nationally Appropriate Mitigation Action: Access to Clean Energy in Rural Kenya through Innovative Market based Solutions. Available at: https:// www.undp.org/content/dam/LECB/docs/pubs-namas/undp-lecb-Kenya_Clean -Energy-NAMA-2016.pdf

Blimpo, M.P. and Malcolm, C.-D. (2019) Electricity Access in Sub-Saharan Africa: Uptake, Reliability, and Complementary Factors for Economic Impact. Africa Development Forum Series. Washington, DC: World Bank. doi:10.1596/978-1-4648-1361-0. License: Creative Commons Attribution CC BY 3.0 IGO 
Boone, C. (2012) 'Land conflict and distributive politics in Kenya', African Studies Review, 55(1), pp. 75-103. https://doi.org/10.1353/arw.2012.0010

Byrne, R., Ockwell, D., Urama, K., Ozor, N., Kirumba, E., Ely, A., Becker, S. and Gollwitzer, L. (2014) Sustainable Energy for Whom? Governing Pro-poor, Low Carbon Pathways to Development: Lessons from Solar PV in Kenya. Brighton: STEPS Centre. Available at: https://core.ac.uk/download/pdf/30610839.pdf

Eberhard, A. and Kåberger, T. (2016) 'Renewable energy auctions in South Africa outshine feed-in tariffs', Energy Science \& Engineering, 4. https://doi.org/10.1002/ese3.118

The Electric Power Act, no. 11 of 1997 (1997) https://www.scribd.com/doc/140005439 /Electrical-Power-Act-1997-kenyan-laws

The Energy Act 2006, no. 12 of 2006, The Government of Kenya (2006) http://ken yalaw.org/kl/fileadmin/pdfdownloads/Acts/EnergyAct_No12of2006.pdf

The Energy Act, 2019, no. 1 of 2019, The Government of Kenya (2019) https://kplc. co.ke/img/full/ec4cPzz9sNDQ_1.\%20ENERGY\%20ACT\%20No.\%201\%20of\%2 02019.PDF

Energy Regulatory Commission (ERC) (2018) 'Approval of the schedule of tariffs set by the energy regulatory commission for supply of electrical energy by Kenya power and lighting company limited pursuant to section 45 of the energy act, 2006', The Kenya Gazette. https://www.epra.go.ke/download/applicable-electricity-tariffs-june $-2019 /$

EPRA (2020) 'Renewable energy registers' in Energy and Petroleum Regulatory Authority. Available at: https://www.epra.go.ke/services/renewable-energy-2/energy-auditfirm-register/

ERC (2008). Kenya Electricity Grid Code. https://eregulations.invest.go.ke/media/kenya $\% 20$ grid $\% 20$ code.pdf

ERC (2012). The Energy (Solar Water Heating) Regulation, 2012. Energy Regulatory Comission of Kenya (ERC).

Farla, J., Markard, J., Raven, R. and Coenen, L. (2012) 'Sustainability transitions in the making: A closer look at actors, strategies and resources', Technological Forecasting E Social Change, 79. https://doi.org/10.1016/j.techfore.2012.02.001

Fast Company (2020) The World's Top 10 Most Innovative Companies of 2015 in Africa, June 24. Available at: https://www.fastcompany.com/3041821/the-worlds-top-10-mostinnovative-companies-of-2015-in-africa

Geels, F.W. (2011) 'The multi-level perspective on sustainability transitions: Responses to seven criticisms', Environmental Innovation and Societal Transitions, 1(1), 24-40. https:// doi.org/10.1016/j.eist.2011.02.002

Geels, F.W. (2014) 'Regime resistance against low-carbon transitions: Introducing politics and power into the multi-level perspective', Theory, Culture \& Society, 31(5), pp. 21-40. https://doi.org/10.1177/0263276414531627

Godinho, C. and Eberhard, A.A. (2019) Learning from Power Sector Reform: The Case of Kenya. Policy research working paper series 8819, pp.53. The World Bank. https://doi .org/10.1596/1813-9450-8819

GoK (2007) Kenya Vision 2030. Kenya: Government Press. https://www.researchict africa.net/countries/kenya/Kenya_Vision_2030_-_2007.pdf

GoK (2010) The Constitution of Kenya, 2010 (Revised Edition, 2010). National Council for Law Reporting with the Authority of the Attorney General. http://vision2030.go. $\mathrm{ke} /$ publication/the-constitution-of-kenya-2010/

GoK (2011) Scaling-up Renewable Energy Program (SREP): Investment plan for Kenya. https:// www.climateinvestmentfunds.org/sites/cif_enc/files/Kenya_post_mission_report_ March_10_2011.pdf 
Hanlin, R. and Okemwa, J. (2022) 'Interactive learning and capability-building in critical projects', in Building Innovation Capabilities for Sustainable Industrialisation: Renewable Electrification in Developing Economies. New York: Routledge. https://doi .org/10.4324/9781003054665-7

Holden, S.T., Otsuka, K. and Place, F.M. (2010) The Emergence of Land Markets in Africa: Impacts on Poverty, Equity, and Efficiency. New York: Routledge. https://www.routledge. com/The-Emergence-of-Land-Markets-in-Africa-Impacts-on-Poverty-Equity-and /Holden-Otsuka-Place/p/book/9781936331666

IEA (2019) Africa Energy Outlook 2019. Available at: www.iea.org/africa2019

KenGen (2020) Who We Are, Accessed on April 30, 2020. Available at: https://kengen.co. ke/index.php/our-company/who-we-are.html

Kenya Power (2004) Annual Financial Statement and Report for the Financial Year Ending June, 2003 [Annual Financial Statements]. https://www.kplc.co.ke/content/item/40 /annual-reports-archives. https://www.kplc.co.ke/AR2004/Annual\%20Reports \%20\&\%20Accounts\%202004-05.pdf

Kenya Power (2013) Annual Report and Financial Statement, 2012 [Annual Financial Statements]. Kenya Power. https://www.kplc.co.ke/content/item/40/annual-reports -archives. https://kplc.co.ke/img/full/0XLOM2rTP95g_KENYA\%20POWER\% 20ANNUAL\%20REPORT\%2020122013\%20FA\%20127,128.pdf

Kenya Power (2018) Annual Report and Financial Statements for the year ended 30 June 2017, p. 200. https://www.kplc.co.ke/content/item/40/annual-reports-archives. https://kplc.co.ke/AR2017/KPLC\%202016\%20-\%202017\%20Annual\%20 Report-.pdf

Kenya Power (2019) Annual Report and Financial Statements for the Year Ended 30th June 2018. https://www.kplc.co.ke/AR2018/KPLC\%20Annual\%20Report\%2017_12 _2018_Wed.pdf

Kenya National Bureau of Statistics (KNBS) (2009) 2009 Kenya Population and Housing Census: Counting our people for implementation of vision 2030 [National Census Report]. Vol II, Kenya National Bureau of Statistics.

Kingiri, A. and Okemwa, J. (2022) 'Local content and capabilities: Policy processes and stakeholders in Kenya', in Building Innovation Capabilities for Sustainable Industrialisation: Renewable Electrification in Developing Economies. New York: Routledge. https://doi .org/10.4324/9781003054665-11

KNBS (2019) Economic Survey, 2019. Government Press. Available at: https://www.knbs. or.ke/?wpdmpro=economic-survey-2019-popular-version

KNBS (2020a) 2019 Kenya Population and Housing Census Volume I: Population by County and Sub-County [Census Report]. Available at. https://www.knbs.or.ke/?wpdmpro $=2019$-kenya-population-and-housing-census-volume-i-population-by-county-and -sub-county

KNBS (2020b) Economic Survey 2020. Available at: https://www.theelephant.info/ documents/kenya-national-bureau-of-statistics-economic-survey-2020/

Kiplagat, J., Wang, R.Z. and Li, T.X. (2011) 'Renewable energy in Kenya: Resource potential and status of exploitation', Renewable and Sustainable Energy Reviews, 15, pp. 2960-2973. https://doi.org/10.1016/j.rser.2011.03.023

Kiprop, E., Matsui, K. and Maundu, N. (2020) 'The future contribution of demand side management to solving Kenya's energy insecurity problems', International Journal of Environmental Science and Development, 11, pp. 111-115. https://doi.org/10.18178/ijesd. 2020.11.3.1235

Gregersen, C. and Gregersen, B. (2022) 'Interactive learning spaces: Insights from two wind power megaprojects', in Building Innovation Capabilities for Sustainable 
Industrialisation: Renewable Electrification in Developing Economies. New York: Routledge. https://doi.org/10.4324/9781003054665-8

Lake Turkana Wind Power Project (2011) Updated Environmental and Social Impact Assessment Summary [Summary Report]. Available at: https://old.danwatch.dk/wp -content/uploads/2016/05/LTWP_ESIA_Executive_Summary_01.pdf

Lawson, B. and Samson, D. (2001) 'Developing innovation capability in organisations: A dynamic capabilities approach', International Journal of Innovation Management, 5(3), pp. 377-400. https://doi.org/10.1142/S1363919601000427

Lema, R., Hanlin, R., Hansen, U.E. and Nzila, C. (2018) 'Renewable electrification and local capability formation: Linkages and interactive learning', Journal of Energy Policy, 117, pp 326-339. Doi: https://doi.org/10.1016/j.enpol.2018.02.011

Mbaka, J. and Mwaniki, M. (2016) 'Small hydro-power plants in Kenya: A review of status, challenges and future prospects', Journal of Renewable Energy and Environment, 3, pp. 20-26. Doi: https://doi.org/10.30501/jree.2016.70096

Ministry of Energy (2011) Updated Least Cost Power Development Plan 2011-2031. http:// kerea.org/wp-content/uploads/2016/08/Least-Cost-Power-Development-Plan-20 11-2031.pdf

Ministry of Energy (2012). Feed-in-Tariffs policy for wind, biomass, small hydros, geothermal, biogas and solar. http://admin.theiguides.org/Media/Documents/FiT\%20Policy\%202 012.pdf

Ministry of Energy and Petroleum (2018) Updated Least Cost Power Development Plan 20172037. https://www.decoalonize.org/2017-2037-least-cost-power-developmentplans-lcpdp/

M-KOPA Solar (2015) M-KOPA: The World's Top 10 Most Innovative Companies of 2015 in Africa. M-KOPA SOLAR, Accessed on February 9, 2020. Available at: http://www. m-kopa.com/m-kopa-featured-as-the-worlds-top-10-most-innovative-companiesof-2015-in-africa/

M-KOPA Solar (2020) Our Impact, M-KOPA Corporate. Accessed in April 16, 2020, Available at: http://solar.m-kopa.com/about/our-impact/

MoE (2004) Sessional Paper No. 4 on Energy. Available at: https://renewableenergy.go.ke/ downloads/policy-docs/sessional_paper_4_on_energy_2004.pdf

MoE (2018) National Energy Policy. Available at: https://kplc.co.ke/img/full/BL4PdOq KtxFT_National\%20Energy\%20Policy\%20October\%20\%202018.pdf

Newell, P., Phillips, J., Pueyo, A., Kirumba, E., Ozor, N. and Urama, K. (2014) 'The political economy of low carbon energy in Kenya', IDS Working Papers, 2014(445), pp. 1-38. https://doi.org/10.1111/j.2040-0209.2014.00445.x

Njiru, C.W. and Letema, S.C. (2018) 'Energy poverty and its implication on standard of living in Kirinyaga, Kenya', Journal of Energy, 2018. Accessed 8 October 2020. Doi: https://doi.org/10.1155/2018/3196567

Nussbaum, M.C. (2001) Women and Human Development: The Capabilities Approach. University of Chicago, Cambridge University Press. Doi: https://doi.org/10.1017/ CBO9780511841286

Ockwell, D., Ely, A., Mallett, A., Johnson, O. and Watson, J. (2009) Low Carbon Development: The Role of Local Innovative Capabilities. STEPS Centre. Available at: https:// opendocs.ids.ac.uk/opendocs/handle/20.500.12413/2459

Regulus Limited (2020) Electricity cost in Kenya. Accessed on 2020, April 30, Available at: https://www.stimatracker.com/

RENCON Consulting (2018) Study on Solar Photovoltaic Industry in Kenya [Draft Report]. Available at: https://www.epra.go.ke/downloads/ 
70 Mbeo Calvince Ogeya et al.

Roux, A. and Shanker, A. (2018) Net Metering and PV Self-consumption in Emerging Countries [Report IEA-PVPS T9-18:2018; IEA PVPS Task 9, Subtask 4], pp. 56. International Energy Agency (IEA). Available at: https://iea-pvps.org/wp-content/ uploads/2020/01/T9_NetMeteringAndPVDevelopmentInEmergingCountries_EN _Report.pdf

Smith, A., Voß, J.-P. and Grin, J. (2010) 'Innovation studies and sustainability transitions: The allure of the multi-level perspective and its challenges', Research Policy, 39(4), pp. 435-448. https://doi.org/10.1016/j.respol.2010.01.023

United Nations (2015) 'About the sustainable development goals', United Nations Sustainable Development. Available at: https://www.un.org/sustainabledevelopment/ sustainable-development-goals/ 